\title{
BENTUK-BENTUK PELANGGARAN PRINSIP KESOPANAN DALAM CERAMAH KEAGAMAAN
}

\author{
Ali Kusno \\ Abd. Rahman
}

alikusnolambung@gmail.com

abd.rahmad_y@yahoo.com

Kantor Bahasa Provinsi Kalimantan Timur

Samarinda, kalimantan Timur, Indonesia

\begin{abstract}
Abtract: A religious lecture is the effective means of propaganda for direct interacting to the worshipers. Unfortunately, there are some lecturers who do not pay attention to the politeness principle in the preaching. One lecturer who often causes controversy is GN. GN lectures on several occasions, such as lectures in churches, sparked debate and a negative response from the other speaker. This research is to reveal the forms of principle courtesy violation in discourse. This research used descriptive qualitative research with discourse analysis approach. The analysis showed the forms of the offense of direct criticism (menohok hearer) with a word or phrase that is abusive, speech-driven sense of emotion, intent cornered hearer, the charges on the basis of suspicion, protective of opinions, attack the personal aspect, and the spread of hatred. The forms of violations that included part of the Approbation Maxim. It can be concluded that the conflict (linguistic and social) can be triggered by a lecture, disregarding the principle of modesty. Linguistic conflict, like debate between lecturers, would arise not because of the debate the substance of propaganda, but the attack triggered a personal aspect and spreading hatred. Conflicts are likely to occur when the violation of the principle of courtesy is still ongoing. The negative impact of the conflict would be stronger if it involves an object or group of people with different religious and ethnic.
\end{abstract}

Keywords: violation, principle of courtesy, religious lecture conflict, provocative lecture

\section{PENGANTAR}

Ceramah merupakan salah satu sarana syiar keagamaan yang efektif. Melalui ceramah, pemuka agama/ulama dapat berinteraksi langsung dengan jamaah. Sebuah ceramah yang baik mampu mempersuasi jamaah ke arah kebaikan. Oleh karena itu, seorang penceramah harus memiliki bekal ilmu agama yang baik. Selain itu, seorang penceramah harus memiliki bekal kemampuan berkomunikasi agar pesan yang disampaikan dapat diterima jamaah dengan baik.

Salah satu penceramah yang memiliki bekal ilmu agama dan kemampuan berkomunikasi yang baik adalah Ustaz Yusuf
Mansyur. Dalam penelitian Penggunaan Gaya Bahasa Ustaz Yusuf Mansyur: Deskripsi atas Tausiah yang Berjudul Kun Fayakun (Kusno, 2015b, h. 1-16) terungkap gaya bahasa retoris Ustaz Yusuf Mansyur dalam menyampaikan tausiah. Hasil penelitian menunjukkan bahwa Ustaz Yusuf Mansyur menggunakan beragam gaya bahasa dalam membawakan tausiah sehingga mudah diterima khalayak dengan beragam tingkatan sosial. Gaya bahasa Ustaz Yusuf Masyur itu di antaranya adalah gaya bahasa Betawi, gaya bahasa percakapan yang digunakan pada keseluruhan tausiah, gaya bahasa mulia dan bertenaga (nada suara rendah, ada suara tinggi, dan memanjangkan pelafalan kata), 
berbagai gaya bahasa repetisi (epizeuksis, anafora, anadikplosis, mesodiplosis), gaya bahasa parabola/parabel, gaya analogi yang panjang, gaya bahasa pertanyaan retoris, gaya bahasa hiperbol, gaya bahasa personifikasi, penggunaan humor, gaya bahasa antiklimaks, dan gaya bahasa klimaks. Penggunaan beragam gaya bahasa itu terbukti efektif karena tausiah Ustaz Yusuf Mansyur menjadi lebih menarik dan pesan yang disampaikan dapat diterima jamaah dengan baik.

Hal itu membuktikan, selain bekal pengetahuan agama, penceramah harus memiliki kemampuan berbahasa yang baik. Sayangnya, tidak semua penceramah memiliki kemampuan dan kesadaran itu. Akibatnya beberapa penceramah mendapat penolakan dari jamaah karena muatan dan penggunaan bahasa dalam ceramah. Selain itu, akibat ceramah yang disampaikan justru mengundang perdebatan dengan penceramah lain. Ceramah seperti itu, selain menyebabkan kesesatan juga menimbulkan penentangan dari kalangan umat.

Salah satu penceramah yang menyita perhatian publik adalah GN (inisial digunakan untuk menjaga nama baik penutur). GN yang bernama lengkap NAH dikenal dengan sikap dan pernyataan yang sering menimbulkan kontroversi di tengah umat dan umat. Seperti diberitakan beberapa media dalam jaringan (daring/online) kontroversi GN bermula karena berceramah di gereja atau pun di kelenteng Khong $\mathrm{Hu} \mathrm{Cu}$. Sepak terjang GN pun menjadi bahan perbincangan dan pergunjingan dalam kalangan umat Islam. Selain itu, sepak terjang GN mengundang tanggapan sesama ulama, baik yang pro maupun yang kontra. Salah satu ulama yang menentang keras gaya dakwah dan ceramah GN adalah HSA. HSA tidak setuju dengan sepak terjang GN yang berceramah di gereja dengan alasan apa pun. Pernyataan dan kritikan HSA itu mendapat tanggapan balik dari GN. Dalam pengajian umum Sholawat dan Pengajian Akbar Peringatan Hari Besar Islam di Masjid Baiturahman yang diunggah di Youtube (Supriyadi, 2015), GN menyayangkan sikap HSA. GN melontarkan pernyataanpernyataan yang menyerang HSA.

Gaya ceramah GN itu terulang dalam kesempatan acara yang lain, yakni pada acara Maulid Nabi Muhammad SAW, 20 Februari 2015, di Masjid Jami Assu'ada Jatinegara
Kaum, Jakarta Timur. Jamaah yang menyimak ceramah GN itu langsung bereaksi. Jamaah, yang didominasi massa Front Pembela Islam (FPI), terprovokasi dengan pernyataanpernyataan GN yang mulai menyinggung halhal di luar substansi tema acara. GN dipaksa berhenti ceramah dan diteriaki untuk turun panggung (Muslimedianews, 2015).

Konflik dalam dua contoh kasus ceramah tersebut merupakan bentuk konflik linguistik. Konflik linguistik antarulama atau pemuka agama dapat melebar ke konflik antarpengikut masing-masing pemuka agama tersebut. Konflik linguistik dapat berupa perselisihan tentang kata siapa yang boleh digunakan, istilah-istilah apa yang digunakan kelompok satu untuk menyebut diri mereka sendiri dan menyebut lawan mereka (Thornborrow, 2006, h. 236). Salah satu konflik linguistik adalah penggunaan istilahistilah dalam menyebut lawan tutur.

Penelitian tentang konflik linguistik yang dikaitkan dengan potensi konflik sosial telah dilakukan Kusno (2016, h. 1-26) dalam makalah yang berjudul Analisis Wacana Percakapan Warga dalam Grup Facebook Bubuhan Samarinda: Identifikasi Potensi Konflik Sosial. Dalam makalah itu diungkapkan bahwa beragam potensi sosial di masyarakat dapat diidentifikasi melalui konflik linguistik yang ada di media sosial. Konflik linguistik merepresentasikan potensi konflik sosial nyata di masyarakat. Konflik linguistik dan dan potensi konflik sosial rentan dimanfaatkan dan dimainkan pihak-pihak yang tidak bertanggung jawab untuk kepentingan tersembunyi, seperti kepentingan politik.

Pemerintah mengeluarkan imbauan untuk menanggapi dan mengantisipasi adanya tindakan dan reaksi masyarakat yang disebabkan ceramah. Menteri Agama, Lukman Hakim Saifuddin, mengharapkan para pendakwah dalam menyampaikan dakwahnya tidak hanya menerangkan, tetapi mencerahkan dan tidak melakukan provokasi melalui dakwah. Menurut Lukman Hakim Saifuddin, dakwah yang mencerahkan lebih luas lagi konteksnya, tidak hanya menjelaskan, tetapi mampu menjelaskan mengapa ada pandangan yang membolehkan dan mengapa ada pandangan yang tidak membolehkan. Masing-masing perlu dijelaskan kepada jamaah sehingga kemudian umat tercerahkan, 
arif, dan tahu ada beragam pandangan di Islam terkait sebuah persoalan (Prihantoro, 2016).

Oleh karena itu, penelitian ini sangat penting untuk mengkaji penggunaan bahasa ceramah yang berpotensi melanggar prinsip kesopanan dan memicu konflik linguistik maupun sosial. Hasil penelitian ini sangat penting sebagai bahan referensi bagi penceramah agar tidak terjebak dengan pola ceramah yang serupa. Apabila pola dakwah seperti itu menggejala dikhawatirkan dapat menimbulkan kebingungan dan juga perpecahan umat.

Penelitian ini menggunakan studi kasus terkait ceramah GN. Rumusan penelitian ini adalah bagaimanakah bentuk-bentuk pelanggaran prinsip kesopanan dalam ceramah keagamaan yang berpotensi memicu konflik. Tujuan penelitian ini untuk mendeskripsikan bentuk-bentuk pelanggaran prinsip kesopanan pemicu konflik dalam ceramah keagamaan. Penilaian bentuk provokasi didasarkan pada penggunaan gaya bahasa maupun substansi ceramah GN. Hasil penelitian ini dapat menjadi bahan rujukan sekaligus masukan dalam pengklasifikasian ceramah keagamaan yang melanggar prinsip kesopanan dan memicu konflik.

\section{Tinjauan tentang Dakwah dan Ceramah}

Menurut Munir (2006, h. 62) dakwah adalah suatu proses penyampaian/penyeruan informasi Ilahiyah kepada para hamba manusia yang merupakan bagian integral dari hidup dan kehidupan setiap individu muslim. Berdasarkan definisi itu dakwah digunakan untuk menyampaikan pesan-pesan kebaikan kepada umat muslim. Metode dakwah yang digunakan cukup beragam. Cukup banyak metode dan strategi dalam berdakwah, seperti ceramah, tausiah, nasihat, diskusi, bimbingan keagamaan, uswah dan qudwah hasanah, dan lain sebagainya (An-Nabiry, 2008, h. 239).

Dalam KBBI Daring (Kemdikbud, 2016) ceramah dimaknai dengan pidato oleh seseorang di hadapan banyak pendengar, mengenai suatu hal, pengetahuan, dan sebagainya. Sebagai pidato yang dibawakan di hadapan banyak pendengar, sebuah ceramah keagamaan harus benar-benar mempertimbangkan secara substansi dan penggunaan bahasanya. Ceramah keagamaan diharapkan berisi pesan-pesan dalam hal kebenaran dan kesabaran. Pesan-pesan kebenaran dan kesabaran hendaknya menggunakan bahasa yang baik. Meskipun demikian, kenyataannya masih terdapat penceramah yang menyampaikan pesanpesan keagamaan dengan menggunakan bahasa provokatif.

Provokatif dalam KBBI Daring (Kemdikbud, 2016) dimaknai bersifat provokasi; merangsang untuk bertindak; bersifat menghasut. Berdasarkan definisi itu tindakan provokatif merupakan upaya merangsang atau menghasut khalayak untuk bertindak. Sedangkan dalam konteks dakwah, memprovokasi, kata Menteri Agama, adalah dakwah yang menyatakan pandanganpandangannya saja yang paling benar, menjelek-jelekkan dan sejenisnya (Prihantoro, 2016). Dengan demikian dapat dipahami bahwa dakwah yang provokatif adalah dakwah yang menyampaikan pandanganpandangan pendakwah saja yang paling benar, bertindak cenderung menjelek-jelekkan dan sejenisnya, berupaya merangsang atau menghasut khalayak. Hasutan dan rangsangan dalam dakwah provokatif tentunya dapat menimbulkan potensi konflik atau perpecahan di kalangan umat dan masyarakat.

\section{Prinsip Kesopanan dalam Ceramah}

Kesopanan merupakan elemen keberterimaan dalam interaksi antarpengguna bahasa. Kesopanan dalam KBBI Daring (Kemdikbud, 2016) dimaknai dengan 1) adat sopan santun; tingkah laku (tutur kata) yang baik; tata krama; 2) keadaban; peradaban; 3) kesusilaan. Kesopanan berdasarkan definisi itu merupakan bentuk adat sopan santun dalam bertingkah laku (tutur kata) yang baik. Sedangkan menurut Leech (1993, h. 161), sopan santun sering diartikan secara dangkal sebagai suatu tindakan yang sekadar beradab, namun makna yang lebih penting yang diperoleh dari sopan santun ialah sopan santun merupakan mata rantai yang hilang antara prinsip kerja sama dengan masalah bagaimana mengaitkan daya dengan makna. Berdasarkan pengertian itu dapat dipahami bahwa pengertian kesopanan berbahasa adalah adat sopan santun tutur kata yang baik yang mengaitkan daya dan makna.

Dalam hal ini peranan sopan santun menjadi penting. Melalui sopan santun dapat 
diungkapkan alasan dalam pemilihan penggunaan bahasa yang mengedepankan sopan santun. Dengan demikian, sopan santun tidak sebatas mengungkapkan cara bertutur yang sopan, tetapi juga mengungkapkan alasan penggunaan bahasa itu. Menurut Rahardi (2005, h. 35) penelitian kesopanan mengkaji penggunaan bahasa (language use) dalam suatu masyarakat bahasa tertentu. Seorang penutur harus memerhatikan prinsip-prinsip kesopanan dalam bertutur. Prinsip kesopanan (politeness principle) tersebut berhubungan dengan dua peserta percakapan, yakni diri sendiri (self) dan orang lain (other) (Wijana, 2009, h. 51). Diri sendiri adalah penutur, dan orang lain adalah lawan tutur, dan orang ketiga yang dibicarakan penutur dan lawan tutur.

Selain memerhatikan pihak-pihak terkait, menurut Chaer (Masfufah, 2013, h. 103) ada tiga hal pokok yang harus diperhatikan dalam memberikan tuturan, yaitu (1) identitas sosial budaya para partisan (penutur dan lawan tutur), (2) topik tuturan, (3) konteks waktu, situasi, dan tempat penuturan berlangsung. Selain itu, dalam tuturan juga dipengaruhi oleh tujuan tuturan. Dengan demikian, dalam bertutur lisan maupun tulisan harus memperhatikan identitas sosial budaya para partisan, topik tuturan, konteks, dan juga tujuan. Hal-hal pokok itu menjadi pertimbangan kesopanan dalam tuturan. Pesan yang disampaikan dapat dengan baik diterima peserta tutur apabila komunikasi yang terjalin mempertimbangkan prinsipprinsip kesopanan berbahasa.

Prinsip kesopanan berbahasa sebagaimana dikemukakan oleh Leech (1993, h. 206-207) yakni sebagai berikut.

a. Maksim kearifan (tact maxim). Buatlah kerugian orang lain sekecil mungkin. Buatlah keuntungan orang lain sebesar mungkin.

b. Maksim kedermawanan (generosity maxim). Buatlah keuntungan diri sendiri sekecil mungkin. Buatlah kerugian diri sendiri sebesar mungkin.

c. Maksim pujian (approbation maxim). Kecamlah orang lain sesedikit mungkin. (Pujilah orang lain sebanyak mungkin.)

d. Maksim kerendahan hati (modesty maxim). Pujilah diri sendiri sesedikit mungkin. (Kecamlah diri sendiri sebanyak mungkin). e. Maksim kesepakatan (agreement maxim). Usahakan agar kesepakatan aantara diri sendiri dan lain tejadi sesedikit mungkin. (Usahakan agar kesepakatan antara diri sendiri dengan orang lain terjadi sebanyak mungkin).

f. Maksim simpati (sympathy maxim). Kurangilah rasa antipati antara diri dengan lain hingga sekecil mungkin. (Tingkatkan rasa simpati sebanyakbanyaknya antara diri dan orang lain).

Pelanggaran terhadap prinsip-prinsip kesopanan itu dapat disebabkan beragam faktor. Pranowo mengungkapkan (2009, h. 68-73) beberapa faktor atau hal yang menyebabkan pelanggaran prinsip kesopanan antara lain.

a. Penutur menyampaikan kritik secara langsung (menohok mitra tutur) dengan kata atau frase yang kasar.

b. Penutur didorong rasa emosi ketika bertutur.

c. Penutur protektif terhadap pendapatnya.

d. Penutur sengaja ingin memojokkan mitra tutur dalam bertutur.

e. Penutur menyampaikan tuduhan atas dasar kecurigaan terhadap mitra tutur.

Faktor-faktor itu selama ini yang menjadi penyebab seseorang melanggar prinsip kesopanan. Dalam konteks lain, selain faktorfaktor itu bisa disebabkan faktor-faktor lain yang mengakibatkan pelanggaran prinsip kesopanan.

Penelitian tentang pematuhan dan pelanggaran prinsip kesopanan pernah dilakukan Kusno (2015a: 65-77) yang berjudul Pematuhan dan Pelanggaran Prinsip Kesopanan Serta Fungsinya dalam Wacana Terkait Usulan Dana Aspirasi DPR di Rubrik Politik Kompasiana. Hasil penelitian menunjukkan bahwa para kompasianer (penulis artikel) mematuhi prinsip-prinsip kesopanan. Prinsip kesopanan yang digunakan meliputi maksim kearifan, maksim pujian, maksim kerendahan hati, maksim kesepakatan, dan maksim simpati. Pematuhan tersebut menunjukkan bahwa kompasianer menempatkan diri sebagai bagian masyarakat. Di sisi lain, pelanggaran prinsip kesopanan meliputi maksim pujian, yakni mengkritik langsung; bertutur kasar, sengaja ingin memojokkan mitra tutur, dan menyampaikan tuduhan atas dasar kecurigaan terhadap mitra tutur. Pelanggaran maksim kesepakatan 
ditunjukkan dengan pertentangan pemahaman mengenai usulan dana aspirasi DPR. Pelanggaran-pelanggaran itu berfungsi untuk menyampaikan kritik pedas kepada anggota DPR.

\section{METODE}

Penelitian ini menggunakan metode penelitian kualitatif yang bersifat deskriptif. Metode penelitian kualitatif merupakan prosedur penelitian yang menghasilkan data deskriptif berupa kata-kata tertulis dan lisan tentang sifat individu, keadaan, gejala dari kelompok tertentu yang dapat diamati (Moleong, 1994, h. 6). Objek penelitian ini adalah penggunaan bahasa dalam ceramah keagamaan GN dalam pengajian umum 'Sholawat dan Pengajian Akbar Peringatan Hari Besar Islam' di Masjid Baiturahman dan pada acara Maulid Nabi Muhammad SAW, 20 Februari 2015, di Masjid Jami Assu'ada Jatinegara Kaum, Jakarta Timur.

Data penelitian ini berupa transkrip rekaman ceramah GN. Sedangkan sumber data dokumen pertama berupa rekaman ceramah GN dalam acara pengajian umum 'Sholawat dan Pengajian Akbar Peringatan Hari Besar Islam' di Masjid Baiturahman (Supriyadi, 2015) yang penulis akses 3 Januari 2016. Data pertama yang masih burupa rekaman video yang selanjutnya penulis transkrip. Data kedua berupa transkrip dan video ceramah GN yang dimuat dalam Muslimedianews (2015) yang diakses 12 Januari 2016. Transkrip kedua data divalidasi ulang dengan video rekaman ceramah untuk memastikan kebenaran dan kelengkapan tuturan.

Penelitian ini menggunakan pendekatan analisis wacana. Prinsip penafsiran dapat melalui penafsiran lokal (termasuk ruang dan waktu) dan prinsip analogi dalam menafsirkan pengertian (makna) yang terkandung di dalam wacana (Djajasudarma, 1993, h. 75). Transkrip rekaman ceramah GN ditafsirkan dengan mempertimbangkan unsur ruang dan waktu serta makna yang terkandung. Pengkajian data dilakukan dengan menginterpretasikan tanda dan makna pesan verbal, serta unsur pemicu konflik dalam ceramah keagamaan GN.

\section{DISKUSI DAN TEMUAN}

Beberapa penceramah dalam menyampaikan dakwahnya dalam substansi maupun penggunaan bahasanya berpotensi menimbulkan konflik, baik linguistik maupun sosial. Salah satu penceramah yang dinilai kontroversial dalam berdakwah adalah GN. GN memang sosok ulama yang unik dan menarik. Seperti dimuat Islamcendekia.com (2015) profil biografi lengkap GN semakin dicari, baik di Wikipedia, Youtube, media sosial, maupun media-media Islam di Indonesia. Nama GN semakin melambung, setelah memimpin Pasukan Berani Mati saat Gus Dur akan dilengserkan. Nama GN juga semakin dikenal publik ketika GN getol ceramah lintas agama di gereja-gereja dan tempat ibadah lainnya, seperti vihara, kelenteng, dan tempat ibadah non-Islam. GN juga menyisipkan isu-isu politik dalam ceramahnya. Dakwah GN menuai kecaman dari berbagai pihak, termasuk kalangan ulama dan kiai sendiri.

Berikut ini bentuk-bentuk pelanggaran prinsip kesopanan ceramah keagamaan GN dalam acara pengajian umum 'Sholawat dan Pengajian Akbar Peringatan Hari Besar Islam' di Masjid Baiturahman dan pada acara Maulid Nabi Muhammad SAW, 20 Februari 2015, di Masjid Jami Assu'ada Jatinegara Kaum, Jakarta Timur.

\section{Ceramah dengan Mengkritik Secara Langsung dengan Kata atau Frasa yang Kasar}

Saat ini, memang tidak dapat dipungkiri telah muncul perbedaan-perbedaan pandangan antarkelompok dalam umat Islam. Hal itu menyebabkan terjadi saling kritik antara pihak satu dan yang lain. GN dalam beberapa ceramah mengkritik secara langsung (menohok) dan menggunakan kata atau frasa yang kasar. Hal itu mengakibatkan ketidaksopanan terlebih GN sebagai seorang pendakwah. Ketidaksopanan ceramah keagamaan GN terlihat dalam ceramah yang dilaksanakan dalam acara pengajian umum 'Sholawat dan Pengajian Akbar Peringatan Hari Besar Islam' di Masjid Baiturahman, seperti dalam kutipan berikut.

(1) Maka orang yang takwa pasti berbuah kebaikan, kata nabi Khoirunas lil anfauhun linas, kalimatnya adalah khoirunas linas, bukan lil muslim bukan lil 
mukmin. Maka ketika engkau berdakwah kemana-mana masuki gereja masuki wihara, kuil, gelandangan, bawah jembatan, datangi mereka! Apalagi masih Indonesia, datangi mereka, datangi semuanya. Lho, apa nggak haram itu, Gus? Sing muni kharam ki Goooblok! (Pengajian di Masjid Baiturahman).

(2) Lha, nek mereka, kamu datang saja tidak pernah, tapi setiap ketemu, kamu kafir! Kafir! Kafir! Bagaimana bisa mengenal Islam. Maka berfikir. Ini ada orang yang ngomong-ngomong, "Woi ini ada kiai NU keluar masuk gereja, baca sholawat." Lho, bagaimana itu hanya Uteke rak bener, cari duit thok. Lho bagaimana? Itu wong dulunya itu sopir bis di Arab, namanya Syech Abdul Kadir. Nama itu nggak boleh pakai Syech itu nggak boleh. Wong Syech itu gelar. Ini karena Bapaknya pengen dia jadi orang hebat saja maka ditambahi Syech Abdul Kodir (Pengajian di Masjid Baiturahman).

(3) ... Yang masuk gereja itu cari uang, ulama cari duit. Uteke Njebluk! (Pengajian di Masjid Baiturahman).

Dalam penggalan ceramah (1), GN menyampaikan bahwa orang yang bertaqwa pasti berbuah kebaikan, kata nabi, "khoirunas lil anfauhun linas," kalimatnya adalah khoirunas linas, bukan lil muslim bukan lil mukmin. Apabila seseorang berdakwah ke mana-mana memasuki gereja memasuki wihara, kuil, gelandangan, bawah jembatan. GN seperti dalam penggalan ceramah itu menyarankan umat Islam untuk mendatangi (berdakwah) kepada pihak-pihak (wihara, kuil, gelandangan, bawah jembatan) tersebut. Bagi GN berdakwah di tempat-tempat itu sangat memungkinkan apalagi masih dalam wilayah Indonesia.

Pandangan GN itu mendapat pertentangan dari ulama-ulama lain, bahkan ada ulama yang mengganggap pendekatan dakwah yang dilakukan GN sebagai sesuatu yang haram. Setelah mendapatkan kritikan itu, GN membalas kritikan dengan pernyataan, ". sing muni kharam ki Goooblok!". Pernyataan itu dalam bentuk bahasa Jawa, yang apabila diartikan, yang bicara haram itu bodoh. GN menganggap ulama yang mengharamkan gaya ceramahnya sebagai orang yang goblok atau bodoh.
GN dalam penggalan ceramah itu mengkritik secara langsung mengena dan menggunakan kata atau frasa yang kasar, yakni kata goblok (bodoh). Pengucapan kata 'goblok' dengan memanjangkan kata, dalam bahasa Jawa, membentuk makna 'sangat goblok' atau 'sangat bodoh.' Hal itu merupakan salah satu bentuk ketidaksopanan.

Selanjutnya, dalam penggalan ceramah (2), GN menyitir pernyataan HSA (salah satu ulama penentang) yang menjelek-jelekkan GN dengan sebutan kafir. GN mempertanyakan HSA kapan bisa mengenal Islam. GN menyerang balik HSA dengan pernyataan, lho bagaimana itu hanya uteke rak bener, cari duit thok (itu bagaimana hanya otaknya yang tidak benar cari uang saja). Bagi penutur Jawa penggunaan kata uteke sebagai bentuk untuk menyerang pemikiran seseorang yang dirasa salah.

Selanjutnya, GN dalam penggalan ceramah (3) itu mengkritik secara langsung (menohok/menusuk hati) dan menggunakan kata atau frasa yang kasar, yakni kata uteke njebluk (otaknya meledak, atau meletus). Penggunaan kata ataupun frasa itu merupakan salah satu bentuk ketidaksopanan. Selain berdampak ketidaksopanan, kritikan secara langsung dan menggunakan kata dan frasa kasar dapat berdampak provokatif. Ceramah GN mengesankan pandanganpandangannyalah yang paling benar. GN cenderung menjelek-jelekkan ulama lain (HSA).

Pernyataan-pernyataan GN dapat merangsang atau menghasut khalayak. Hasutan dan rangsangan dalam ceramah yang bernuansa provokatif tentunya berpotensi menimbulkan konflik atau perpecahan di kalangan umat. Apalagi, GN dan HSA samasama memiliki basis jamaah/pendukung yang banyak. Apabila pertentangan yang terjadi antara kedua ulama tersebut tidak dimaknai dengan bijak, dapat menimbulkan perpecahan dan konflik di kalangan umat Islam.

\section{Ceramah Didorong Rasa Emosi}

Perasaan marah atau emosi yang berlebihan ikut mewarnai ceramah GN dalam beberapa kesempatan. Penggunaan ceramah dengan didasari rasa emosi terlihat dalam penggalan ceramah yang dilaksanakan dalam acara pengajian umum 'Sholawat dan 
Pengajian Akbar Peringatan Hari Besar Islam' di Masjid Baiturahman berikut ini.

(4) Ngaku mustasar NU. Saya ini dari bayi pengurus Anshor komandan Banser sekarang jadi komandan Pagar Nusa se Indonesia. Pengurus NU, PASU panglima pasukan berani mati bukan panglima banser. Pasukan Panglima Berani mati ini (Pengajian di Masjid Baiturahman).

(5) ... Jangan kemudian ngomong di luar ini ada kiai ngaku NU ngaku Gus ceramah di ini masak tolaalbadru disuruh masuk gereja. Lho kalau memang bener tolaalbadru masuk gereja gerejanya kan jadi masjid. Goblok kok ora dienggu itu lho (Pengajian di Masjid Baiturahman).

Dalam penggalan ceramah (4) itu, GN menyindir HSA, “... ngaku mustasar NU.” GN dengan didorong emosi mengatakan bahwa sejak bayi pengurus Anshor komandan Banser sekarang jadi komandan Pagar Nusa seIndonesia. Pengurus NU, PASU Panglima Pasukan Berani Mati bukan Panglima Banser. Dorongan rasa emosi dalam penggalan ceramah itu sangat terasa. Gus Nuril membawa-bawa nama Anshor, Banser, Pagar Nusa, dan PASU. Selain sebagai bentuk pelanggaran kesopanan, hal itu menimbulkan makna di kalangan jamaah, bahwa GN mengatasnamakan lembaga atau organisai tersebut.

Pernyataan-pernyataan GN itu dapat berdampak provokatif. Ceramah GN mengesankan diri lebih hebat dan pantas diperhitungkan. Pernyataan-pernyataan GN dapat merangsang atau menghasut khalayak khususnya orang-orang yang terkait dengan Anshor, Banser, Pagar Nusa, dan PASU. Hasutan dan rangsangan dalam ceramah yang bernuansa provokatif tentunya dapat menimbulkan konflik atau perpecahan di kalangan umat.

Sedangkan dalam penggalan ceramah (5), GN tampak emosional dengan adanya tuduhan yang dialamatkan kepada dirinya. HSA menyudutkan GN karena kebiasaannya berceramah di gereja-gereja. GN mengkritik dan menyayangkan balik HSA yang 'ngomong di luar' (menyampaikan kritikan dalam berbagai kesempatan) yang menjelek-jelekkan gaya dakwah dan ceramah GN.

GN membela diri bahwa "... kalau memang bener tolaal badru masuk gereja, gerejanya kan jadi masjid." Selain itu, GN menyerang balik HSA dengan pendapatnya yang dirasa salah dan mengatakan bahwa HSA, "... goblok kok ora dienggu itu lho." Pernyataan itu merupakan bahasa Jawa, yang artinya bodoh kok tidak dipakai itu (otak), lho. GN menyerang balik bahwa tuduhan HSA sebagai bentuk pemikiran yang bodoh dan tidak menggunakan otak untuk memikirkannya.

Ceramah GN yang cenderung emosional tersebut dapat berdampak provokatif. Ceramah GN cenderung menyampaikan pandangan-pandangan GN saja yang paling benar. GN bertindak cenderung menjelekjelekkan dan sejenisnya, berupaya merangsang atau menghasut khalayak untuk mengikuti pemikirannya. GN juga membawabawa nama NU, Anshor, PASU Panglima Pasukan Berani Mati. Hal itu dapat memprovokasi para jamaah maupun pengikut masing-masing, baik GN maupun HSA. Selain itu, ceramah GN dapat menimbulkan kebingungan umat tentang figur ulama yang harus diikuti.

\section{Ceramah dengan Memojokkan Mitra Tutur}

Ceramah yang memojokkan mitra tutur secara sengaja menjadikan tuturan tidak sopan. Ketidaksopanan ditunjukkan melalui pilihan-pilihan kata yang membuat lawan tutur terpojok dan disalahkan. Penggalan ceramah berikut berisi pernyataan GN dalam acara pengajian umum 'Sholawat dan Pengajian Akbar Peringatan Hari Besar Islam' di Masjid Baiturahman dan pada acara Maulid Nabi Muhammad SAW, 20 Februari 2015, di Masjid Jami Assu'ada Jatinegara Kaum, Jakarta Timur yang memojokkan mitra tutur.

(6) Maka kalau suaranya bagus silahkan lah. Tapi mbarang sholawat boleh, mbarang sholawat mengutamakan sholawat nabi aja dia sudah dapat bayaran 60 juta 70 juta sekian. Silahkan. Tapi jangan ikut-ikut ngomong soal agama. Ora mudeng. Mung suarane apik thok mbarang sholawat ae. Tapi jangan ngomong-ngomong soal ilmu nanti malah nabrak yang lain-lain (Pengajian di Masjid Baiturahman).

(7) ... bagi saya, saya baru pertama kali ini menghadiri pengajian yang diadakan di tengah jalan. Karena saya keliling sampai ke Yordan kemarin ceramah di Jeddah diundang oleh ulama-ulama Jeddah tidak di jalan begini. Ini saking luar biasanya. Mudah-mudahan nanti Gubernurnya 
menyediakan lapangan yang bisa untuk pengajian. Ndak usah mbok amini wong Gubernure ora ngerti agomo. Sampeyan minta saja daripada mereka. Jangan diamini. Minta disediakan satu lapangan ben bisa nggo ngaji. Gubernure wong ora ngerti ngaji (Pengajian di Masjid Assu'ada).

Dalam penggalan ceramah (6) itu, GN memojokkan HSA, “...maka kalau suaranya bagus silahkan lah. Tapi mbarang sholawat boleh, mbarang sholawat mengutamakan sholawat nabi aja dia sudah dapat bayaran 60 juta 70 juta sekian." Maksud pernyataan itu adalah GN mengakui suara HSA bagus. Menurut GN hanya dengan menggunakan sholawat nabi, HSA sudah mendapatkan pembayaran sampai dengan enam puluh hingga tujuh puluh juta rupiah, atau bahkan lebih dari itu.

Selain itu, GN juga memojokkan mitra tutur (HSA), " jangan ikut-ikut ngomong soal agama. Ora mudeng (tidak paham). Mung suarane apik thok mbarang sholawat ae (Hanya suaranya yang bagus untuk urusan sholawat saja). Tapi jangan ngomongngomong soal ilmu nanti malah nabrak yang lain-lain". Dalam penggalan ceramah itu GN memojokkan dan merendahkan pemahaman agama HSA. Selain itu, GN juga memojokkan HSA bahwa kompetensi yang dimiliki HSA hanya bernyanyi sholawatan.

Ceramah GN yang memojokkan mitra tutur (HSA) tersebut berdampak provokatif. Dalam ceramah itu terdapat kecenderungan bahwa pandangan-pandangan GN saja yang paling benar. GN bertindak menjelek-jelekkan dan sejenisnya, berupaya merangsang atau menghasut khalayak untuk mengikuti pemikirannya. Penghinaan sekaligus provokasi itu dapat memicu tindakan anarki jamaah/pengikut HSA.

Selanjutnya, dalam penggalan ceramah (7), GN menyampaikan, “... bagi saya, saya baru pertama kali ini menghadiri pengajian yang diadakan di tengah jalan. Karena saya keliling sampai ke Yordan kemarin ceramah di Jeddah diundang oleh ulama-ulama Jeddah tidak di jalan begini. Ini saking(karena begitu) luar biasanya. Mudah-mudahan nanti Gubernurnya menyediakan lapangan yang bisa untuk pengajian. Ndak usah mbok amini wong Gubernure ora ngerti agomo (tidak usah kalian amini, Gubernurnya saja tidak mengerti/tahu tentang agama). Sampeyan(kalian) minta saja daripada mereka". Dalam pernyataan itu GN menyayangkan pengajian yang dilaksanakan di jalanan tidak seperti yang dihadirinya ketika ceramah di Yordania. Bagi GN, hal itu sungguh luar biasa. Luar biasa dalam konteks tersebut merupakan ironi sesuatu yang memprihatinkan.

GN meminta masyarakat bisa mengajukan ke Gubernur DKI Jakarta agar disediakan satu lapangan untuk dapat digunakan sebagai tempat pengajian (kegiatan keagamaan). Namun, pernyataan itu hanya sebuah ironi karena setelah itu GN meminta masyarakat tidak mengamini, karena hal itu merupakan sesuatu yang mustahil. Pemahaman itu didasari alasan GN bahwa seorang Gubernur DKI Jakarta (Ahok) tidak mengerti/mengetahui tentang agama.

Kesengajaan GN memojokkan mitra tutur merupakan bentuk ketidaksopanan. Selain itu, dapat memicu provokasi bagi HSA, habibhabib di DKI Jakarta, Ahok, Presiden Jokowi, dan masyarakat. Terutama pernyataan yang berbau SARA, terkait etnis Cina, sangat sensitif bagi masyarakat dapat mengulang berbagai kerusuhan etnisitas yang pernah terjadi di DKI Jakarta. Ceramah GN yang sengaja memojokkan mitra tutur tersebut berdampak provokatif dan dapat menimbulkan konflik. Ceramah provokatif GN cenderung menyampaikan pandangan-pandangan pendakwah saja yang paling benar. GN bertindak cenderung menjelek-jelekkan dan sejenisnya, berupaya merangsang atau menghasut khalayak.

\section{Ceramah dengan Menyampaikan Tuduhan atas Dasar Kecurigaan}

Kecurigaan yang disampaikan penutur kepada mitra tutur dengan melontarkan beragam tuduhan menjadikan tuturan tidak sopan. Ceramah GN dalam acara Maulid Nabi Muhammad SAW, 20 Februari 2015, di Masjid Jami Assu'ada Jatinegara Kaum, Jakarta Timur terdapat ttuturan yang berisi tuduhan atas dasar kecurigaan.

(8) ... tanggal 1 ada haul cucunya Sunan Giri yang ke urutuan yang kelima. Yaitu canggah saya namanya Sulthon Abdul Hamid di daerah ujjung pangkah gresik. Setelah itu saya umroh lagi. Karena apa? Ndongakke (Mendoakan) Indonesia supaya tentrem (tentram). Karena apa, 
karena Indonesia ini kaya guyonan. Menentikan KPK, polisi, kapolri ra bar bar (tidak selesai-selesai). Nggak selesaiselesai. Debaaat gak rampung-rampung (tidak selesai-selesai). Karena apa, karena belum menyadari dan belum mengenal bagaimana cara style of leadership. Gaya kepemimpinan Nabi Allah Agung Muhammad S.A. W. Kalau dia tahu selesai sudah. Indonesia ini paling gampang. Tapi karena gak paham ngaji (Pengajian di Masjid Assu'ada).

(9) ... maka jangan bingung kalau ada Kapolri dan KPK geger itu. Gak usah bingung. Lha terus bolo siapa Gus? Gak usah bolo (teman) Kapolri, gak usah bolo (teman) KPK. Lha terus bagaimana? Tonton saja itu dagelannya Jokowi. ... (Pengajian di Masjid Assu'ada).

(10) Ini Kenapa kok dibikin ruwet begini? Karena sesungguhnya untuk mengalihkan isu bahwa kelompok Ihwanul muslimin, kelompok wahabi, dan ada kelompok HTI. Saya cetho-cethonan(terang-terangan) ini ngomong. Hizbut tahrir, Hizbut tahrir itu adalah perkawinan Ihwanul muslimin dan wahabi. Maka melahirkan suatu bentuk gerakan yang sangat berbahaya (Pengajian di Masjid Assu'ada).

Dalam penggalan ceramah (8), GN menyampaikan agenda untuk umroh lagi. Hajat umroh GN didasari untuk mendoakan Indonesia supaya tentram dengan tuturan, "...itu perlu karena Indonesia ini sudah seperti guyonan, bahan candaan saja. Contoh nyatanya dala menentukan KPK, polisi tidak selesai-selesai". GN mencurigai hal itu disebabkan Presiden Jokowi belum menyadari dan mengenal cara kepemimpinan dan gaya kepemimpinan Nabi Allah yang agung Muhammad SAW. Menurut GN, apabila Presiden Jokowi mengetahuinya, pasti sudah mampu menyelesaikan berbagai persoalan bangsa. GN pun mengkritik dan menyerang Presiden Jokowi tidak paham pola kepemimpinan ala Nabi Muhammad SAW karena tidak paham 'ngaji' atau agama.

Sedangkan dalam penggalan ceramah (9), GN menyampaikan tuduhan terkait kisruh Kapolri dengan KPK dengan tuturan, “...maka jangan bingung kalau ada Kapolri dan KPK geger itu. Gak usah bingung. Lha terus bolo siapa Gus? Gak usah bolo (teman) Kapolri, gak usah bolo (teman) KPK". GN menyampaikan kecurigaan bahwa kekisruhan Kapolri dengan KPK sengaja dibiarkan sebagai bentuk, "dagelannya Jokowi". Menurut GN hal itu sebagai upaya untuk pengalihan isu yang lebih besar, “...ini Kenapa kok dibikin ruwet begini? Karena sesungguhnya untuk mengalihkan isu bahwa kelompok Ihwanul muslimin, kelompok wahabi, dan ada kelompok HTI". Ceramah GN yang cenderung menuduh atas dasar kecurigaan dapat berpotensi provokatif dan memicu konflik. Ceramah GN cenderung menjelek-jelekkan Presiden Jokowi. Hal itu dapat merangsang atau menghasut khalayak untuk membenci pemerintah.

Selanjutnya, seperti dalam pernyataan (12) GN menyampaikan bahwa Hizbut Tahrir itu adalah perpaduan Ihwanul muslimin dan wahabi. Perpaduan itu melahirkan suatu bentuk gerakan yang sangat berbahaya. Bagi GN gerakan seperti HTI merupakan bentuk gerakan yang sangat berbahaya. Ceramah GN yang cenderung menyampaikan tuduhan atas dasar kecurigaan terhadap HTI itu berpotensi provokatif dan memicu konflik.

\section{Ceramah yang Protektif terhadap Pendapat Pribadi}

GN selama ini dikenal publik karena getol ceramah lintas agama di gereja-gereja dan tempat ibadah lainnya, seperti vihara, kelenteng, dan tempat ibadah non-Islam lainnya. Dakwah GN menuai kecaman dari berbagai pihak, termasuk ulama dan kiai sendiri. Meskipun menyadari gaya dakwah dan ceramahnya menjadi sorotan dan bahan perdebatan di masyarakat utamanya umat Islam, GN tetap kukuh dengan pandangannya. Justru GN cenderung protektif dan menutup diri dari kritikan-kritikan yang dilontarkan kepadanya.

Hal itu tampak seperti dalam penggalan pernyataan GN saat berceramah pada acara pengajian umum 'Sholawat dan Pengajian Akbar Peringatan Hari Besar Islam' di Masjid Baiturahman (dalam data (1), (2), dan (3) yang telah dianalisis). Secara terangterangan dan menohok, menggunakan kata dan frasa kasar, GN menyerang balik HSA yang melontarkan kritikan kepadanya. GN protektif terhadap pendapatnya bahwa apa yang dilakukan sudah benar.

Sikap serupa juga ditunjukkan GN saat ceramah pada acara Maulid Nabi Muhammad SAW, 20 Februari 2015, di Masjid Jami 
Assu'ada Jatinegara Kaum, Jakarta Timur. GN begitu protektif terhadap pendapatnya ketika memberikan kritikan terhadap Presiden Jokowi. GN terkesan bahwa analisisnya benar terkait berbagai persoalan bangsa dan perlu diketahui jamaah. Meskipun mendapat reaksi penentangan dari jamaah atas isi ceramah yang disampaikan, GN tetap melanjutkan ceramahnya dengan tidak mengalihkan topik pembicaraan. Sikap protektif terhadap pendapat itulah yang dapat menimbulkan provokasi kepada jamaah. Terbukti, jamaah yang terprovokasi pun menghentikan secara paksa ceramah GN.

Bentuk-bentuk pelanggaran prinsip kesopanan tersebut merupakan bentuk pelanggaran seperti yang diungkapkan Pranowo (2009: 68-73). Berdasarkan analisis data terdapat temuan bentuk-bentuk lain pelanggapan prinsip kesopanan dalam ceramah keagamaan.

\section{Ceramah yang Menyerang Aspek Pribadi Lawan Tutur}

Terjadinya konflik linguistik antara GN dan HSA terjadi karena keduanya saling serang aspek pribadi. Konflik linguistik berupa saling serang pernyataan itu memicu kemarahan keduanya. Kedua pihak saling menyerang aspek latar belakang aspek pribadi. Berikut ini beberapa penggalan yang menunjukkan adanya saling serang aspek pribadi itu.

(11) Lha, nek mereka, kamu datang saja tidak pernah, tapi setiap ketemu, kamu kafir! Kafir! Kafir! Bagaimana bisa mengenal Islam. Maka berfikir. Ini ada orang yang ngomong-ngomong, "Woi ini ada kiai NU keluar masuk gereja, baca sholawat." Lho, bagaimana itu hanya Uteke rak bener, cari duit thok. Lho bagaimana? Itu wong dulunya itu sopir bis di Arab, namanya Syech Abdul Kadir. Nama itu nggak boleh pakai Syech itu nggak boleh. Wong Syech itu gelar. Ini karena Bapaknya pengen dia jadi orang hebat saja maka ditambahi Syech Abdul Kodir (Pengajian di Masjid Baiturahman).

Dalam data (11) GN juga menyinggung latar belakang pribadi HSA, “... itu wong dulunya itu sopir Bis di Arab, namanya Syeach Abdul Kadir. Nama itu nggak boleh pakai Syech itu nggak boleh. Wong Syech itu gelar. Ini karena Bapaknya pengen dia jadi orang hebat saja maka ditambahi Syech Abdul Kodir," (itu orang dulunya sopir bis. Namanya Syech Abdul Kadir. Nama itu tidak boleh dipakai syech begitu. Syech merupakan gelar. Itu karena Bapaknya ingin anaknya jadi orang hebat maka ditambahi dengan Syech Abdul Kodir).

GN menyerang kehidupan pribadi HSA dalam penggalan ceramah (11), yakni kata “...hanya uteku rak bener, cari duit thok, dan itu wong dulunya itu sopir Bis di Arab itu wong dulunya itu sopir Bis di Arab". Penyerangan aspek pribadi itulah yang memicu pelanggaran prinsip kesopanan dan berpotensi memancing emosi lawan tutur. GN juga menyerang aspek pribadi HSA dengan frasa kasar, "uteke rak bener" (otaknya tidak benar). Secara keseluruhan pernyataan GN itu, menyerang HSA yang mengadakan tabligh akbar dengan tarif/pembayaran yang mahal. HSA dituduh menggunakan syiar agama dengan motif untuk mendapatkan uang atau keuntungan finansial saja.

GN juga menyerang aspek pribadi HSA dengan tuturan lain.

(12)... Yang masuk gereja itu cari uang, ulama cari duit. Uteke Njebluk! (Pengajian di Masjid Baiturahman).

Dalam penggalan ceramah (12) itu, GN menyindir dan menepis tuduhan yang dialamatkan kepada dirinya bahwa ada ulama yang masuk gereja itu (GN) mencari uang, atau kategori ulama yang mencari uang. GN membalas tuduhan HSA dengan kata atau frase kasar .."Uteke njebluk!" (otaknya meledak, atau meletus). Ungkapan itu sebagai bentuk kekesalan dan merendahkan pemikiran lawan tutur.

\section{Ceramah dengan Menyebarkan Kebencian}

Setiap ceramah sudah memiliki tema yang ditentukan panitia kegiatan. Tema itulah yang menjadi batasan bagi penceramah dalam menyampaikan ceramah. Sering seorang penceramah keluar dari tema sebagai bentuk selingan untuk mengurangi kejenuhan. Hanya saja selingan ceramah justru menjadi masalah apabila mendominasi dan menyinggung atau menyerang pihak-pihak lain. Hal itu terjadi pada ceramah GN seperti dalam penggalan data berikut.

(13) Dan aneh, di Jakarta ini kan hebat-hebat. Habibnya paling buanyak se-Indonesia. Tapi duwe gubernur ae Cino. Tapi Cino kae 
yo gubernur. Tapi gubernur tapi cino (Pengajian di Masjid Assu'ada).

Dalam penggalan ceramah (13), GN menyampaikan materi ceramah yang lepas dari konteks tema Maulid Nabi Muhammad SAW. GN justru menyampaikan materi ceramah yang menyudutkan para Habib di Jakarta. Menurut GN, Jakarta sebagai sebuah kota yang hebat karena memiliki jumlah habib paling banyak se-Indonesia. GN menyayangkan DKI Jakarta yang justru memiliki Gubernur etnis Cina, dengan pernyataan, "...duwe Gubernur ae Cino. Tapi Cino kae yo gubernur. Tapi gubernur tapi cino" (punya gubernur saja Cina. Tapi Cina-cina gitu ya Gubernur. Tapi Gubernur tapi Cina). Pernyataan itu jelas-jelas memojokkan para habib di Jakarta karena dinilai tidak berdaya, buktinya Gubernur DKI Jakarta justru orang keturunan Cina. Selain itu, GN juga memojokkan Ahok, selaku Gubernur DKI Jakarta, sebagai etnis Cina yang tidak seharusnya memimpin DKI Jakarta. Ceramah GN tersebut jelas-jelas menyebarkan kebencian umat terhadap etnis Cina di Jakarta.

Hal yang sama juga tampak dalam penggalan ceramah berikut.

(14)Saya jadi mumet (pusing). Ngeliat presiden sampeyan (kalian). Presiden blusukan. lho jangan ditertawai sampeyan pilih sendiri. Iya opo (apa) ya. Dipilih presidennya karena blusukkan. Padahal tukang golek beling (tukang cari pecahan kaca) itu tukang blusukkan... (Pengajian di Masjid Assu'ada).

Dalam penggalan ceramah (14), GN juga menyampaikan materi yang keluar dari tema Maulid Nabi Muhammad SAW. GN justru memojokkan Presiden Jokowi. Dalam ceramah itu GN seolah-olah tidak mengakui Presiden Jokowi sebagai presiden dengan pernyataan, “...ngeliat presiden sampeyan" (melihat Presiden kalian). Penggunaan kata 'kalian' dimaknai bahwa GN sebagai penutur tidak ikut terlibat dan tidak merasa bahwa Presiden Jokowi sebagai seorang presiden. Selain itu, GN memojokkan dan menjelek-jelekkan Presiden Jokowi dengan sebutan, “...presidennya karena blusukkan". Yang dipersamakan dengan tukang mencari pecahan kaca, "...padahal tukang golek beling beling (tukang cari pecahan kaca) itu tukang blusukkan". Pernyataan tersebut jelas-jelas memojokkan Jokowi sebagai seorang presiden. Selain itu, GN memprovokasi jamaah untuk membenci Presiden Jokowi yang dinilainya tidak layak menjadi seorang presiden.

Berdasarkan analisis bentuk-bentuk pelanggaran prinsip kesopanan dalam ceramah keagamaan tersebut termasuk bagian dari pelanggaran Maksim Pujian (Approbation Maxim). Sebuah pelanggaran maksim pujian dilakukan dengan memberikan kecaman keras sehingga cenderung merendahkan dan menjelek-jelekkan pihak lain. Dalam dua ceramah itu GN terbukti melontarkan kecaman keras. Hal itu cenderung merendahkan dan menjelekjelekkan pihak lain.

Ceramah seperti yang disampaikan GN, dapat memicu konflik karena bentuk-bentuk pelanggaran prinsip kesopanan, berupa tuturan mengkritik secara langsung dengan kata atau frasa yang kasar, bertutur dengan didorong rasa emosi, memojokkan mitra tutur, menyampaikan tuduhan atas dasar kecurigaan terhadap mitra tutur, protektif terhadap pendapatnya, adanya penyerangan terhadap aspek pribadi lawan tutur, dan menyebarkan kebencian. Ceramah yang melanggar prinsip kesopanan cenderung menimbulkan konflik linguistik. Begitu pula konflik linguistik antarulama atau pemuka agama dapat melebar ke konflik sosial yang melibatkan pengikut/jamaah masing-masing.

Oleh karena itu, penceramah harus memiliki bekal agama dan kemampuan berbahasa yang baik. Dakwah tidak hanya menerangkan, tetapi juga harus mencerahkan. Penceramah berkewajiban menjelaskan kepada jamaah dengan baik sehingga umat tercerahkan, arif, dan tahu ada beragam pandangan di Islam terkait sebuah persoalan. Dengan penggunaan bahasa yang baik, pesanpesan kebaikan akan dapat diterima dengan baik pula oleh jamaah.

\section{SIMPULAN}

Berdasarkan analisis terdapat temuan bentuk-bentuk pelanggaran prinsip kesopanan dalam sebuah ceramah, yakni menyampaikan kritik secara langsung (menohok mitra tutur) dengan kata atau frasa yang kasar, seperti goooblok!, uteke rak bener, cari duit thok, Uteke Njebluk!; didorong rasa emosi ketika bertutur; sengaja ingin memojokkan mitra tutur dalam bertutur; 
menyampaikan tuduhan atas dasar kecurigaan terhadap mitra tutur; dan protektif terhadap pendapatnya, menyerang aspek pribadi, dan menyebarkan kebencian. Bentuk-bentuk pelanggaran prinsip kesopanan itu termasuk bagian dari pelanggaran maksim pujian (Approbation Maxim).

Dengan demikian dapat disimpulkan bahwa konflik (linguistik maupun sosial) dapat dipicu oleh sebuah ceramah yang tidak mengindahkan prinsip-prinsip kesopanan bertutur. Konflik di kalangan umat dan masyarakat dapat dipicu bentuk-bentuk pelanggaran prinsip kesopanan, khususnya bentuk pelanggaran seperti menyerang aspek pribadi dan menyebarkan kebencian.

Konflik linguistik yang timbul antarpenceramah dan pendakwah justru bukan karena perdebatan substansi dakwah, melainkan penyerangan aspek pribadi dan penyebarkan kebencian. Konflik linguistik akan lebih sering terjadi apabila penyerangan terhadap aspek pribadi dan penyebaran kebencian masih terus berlangsung. Penyerangan terhadap aspek pribadi dengan menyebarkan kebencian akan semakin kuat dampak negatifnya apabila melibatkan objek orang dengan agama dan kesukuan yang berbeda. Hal itu terbukti dalam konflik-konflik sosial yang pernah dan sedang terjadi di Indonesia.

Sangat disayangkan adanya bentukbentuk pelanggaran prinsip kesopanan yang dilakukan penceramah. Sebagai seorang ulama/pemuka agama seharusnya memberikan teladan pencerahan bagi umat. Pelanggaran prinsip kesopanan dalam sebuah ceramah berpotensi menimbulkan resistensi bagi umat Islam maupun masyarakat Indonesia. MUI sebagai wadah yang menaungi sebaiknya proaktif memberikan teguran kepada ulama yang menyampaikan ceramah yang melanggar prinsip kesopanan yang cenderung provokatif.

Penelitian lanjutan terkait bentuk-bentuk pelanggaran prinsip kesopanan cenderung provokatif dalam ceramah keagamaan perlu terus dikembangkan. Penelitian terkait bentuk-bentuk radikalisme bahasa dalam ceramah akan lebih menarik dan bermanfaat. Penelitian lintas disiplin ilmu akan dapat memformulasikan indikator-indikator ceramah keagamaan yang berpotensi menimbulkan konflik di masyarakat.

\section{DAFTAR PUSTAKA}

An-Nabiry, Fathul Bahri. (2008). Meniti Jalan Dakwah Bekal Perjuangan Para Da'i. Jakarta: Amzah.

Djadjasudarma, Fatimah. (1993). Metode Linguistik: Ancangan Metode Penelitian dan Kajian. Bandung: Eresco.

Islamcendekia.com. (2015). Biografi Lengkap Gus Nuril Arifin Husein. http://www.islamcendekia.com/2015/08/biografi-lengkap-gus-nuril-arifin-husein.html. Diakses pada tanggal 30 Mei 2016.

Kemdikbud. (2016). KBBI Daring. http://badanbahasa.kemdikbud.go.id/kbbi/index.php. Diakses tanggal 3 April 2016.

Kusno, A. (2015a). Pematuhan dan Pelanggaran Prinsip Kesopanan Serta Fungsinya dalam Wacana Terkait Usulan Dana Aspirasi DPR di Rubrik Politik Kompasiana. Jurnal Ilmiah Bahasa dan Kesastraan Widyaparwa. 43 (1), 65-77.

Kusno, A. (2015b). Penggunaan Gaya Bahasa Ustaz Yusuf Mansyur: Deskripsi atas Tausiah yang Berjudul Kun Fayakun. Jurnal Bahasa Dan Sastra Bebasan, 3 (1 ), 1-16.

Kusno, A. (2016). Analisis Wacana Percakapan Warga dalam Grup Facebook Bubuhan Samarinda: Identifikasi Potensi Konflik Sosial. The 1'st International Conference on Social Sciences and 
Humanities (CSSH). 18-20 Oktober 2016. Jakarta: Kedeputian Bidang Ilmu Sosial dan Kemanusiaan LIPI.

Leech, Geoffrey. (1993). Prinsip-prinsip Pragmatik. Jakarta: Penerbit Universitas Indonesia

Masfufah, Nurul. (2013). 'Ketidaksantunan Berbahasa di SMAN 1 Surakarta: Sebuah Kajian Sosiopragmatik'. Dalam Yudianti Herawati (Ed). Benua Etam: Bunga Rampai Penelitian Kebahasaan dan Kesastraan. 99-122. Yogyakarta: Azzagrafika.

Moleong, L. J. (1994). Metodologi Penelitian Kualitatif. Bandung: Remaja Rosdakarya.

Munir, M. (2006). Metode Dakwah. Jakarta: Kencana.

Muslimedianews. 2015. Transkip Ceramah Gus Nuril 'Diusir' di Jatinegara + Video dan Pernyataan Panitia. $\quad$ http://www.muslimedianews.com/2015/02/transkip-ceramah-gus-nuril-diusirdi.html\#ixzz41d9cmEK3. Diakses tanggal 12 Januari 2016.

Pranowo. (2009). Berbahasa Secara Santun. Yogyakarta. Pustaka Pelajar.

Prihantoro, Anom. (2016). Pendakwah harus Mencerahkan dan jangan Provokatif. http://www.antaranews.com/berita/540433/pendakwah-harus-mencerahkan-dan-janganprovokatif. Diakses pada tanggal 3 Januari 2016.

Rahardi, Kunjana. (2005). Pragmatik: Kesantunan Imperatif Bahasa Indonesia. Yogyakarta: PT Gelora Aksara Pratama.

Sumadiria, Haris AS. (2006). Bahasa Jurnalistik: Panduan Praktis Penulis dan Jurnalis. $\quad$ Badung: Simbiosa Rekatama Media

Supriyadi, Arie. (2014). Ceramah Gus Nuril Masjid Baiturahman. https://www.youtube.com/watch?v=BJZYu8pE70o. Diakses tanggal 3 Januari 2016.

Thornborrow, J. (2006). Bahasa dan Identitas. In Bahasa, Masyarakat, \& Kekuasaan (I, pp. 223251). Malang: Pustaka Pelajar.

Wijana, I Dewa Putu dan Mohammad Rohmadi. (2009). Analisis Wacana Pragmatik: Kajian Teori dan Analisis. Surakarta: Yuma Pustaka. 